\title{
CLASSIFICATION OF THREATS TO THE SOCIO-ECONOMIC SECURITY OF THE COUNTRY
}

CShvaiba D., ORCID: 0000-0001-6783-9765; Ph.D., Belarusian Trade Union of workers of chemical, mining and oil industries; Belarusian national technical University,

Minsk,Belarus,shvabia@tut.by

\section{КЛАССИФИКАЦИЯ УГРОЗ СОЦИАЛЬНО-ЭКОНОМИЧЕСКОЙ БЕЗОПАСНОСТИ СТРАНЫ}

СШвайба Д. H., ORCID: 0000-0001-6783-9765; канд. экон. наук, Белорусский профсоюз работников химической, горной и нефтяной отраслей промышленности; Белорусский национальный технический университет, г. Минск, Беларусь, shvabia@ tut.by

Abstract. Danger in General, and not only socio-economic, is considered such due to the fact that it creates a threat of destruction of the object or harms it. The danger of socio-economic security has the ability to be defined in the final form as some harm, an integral indicator of which characterizes the level of decline in socio-economic potential for a specific time. The danger is understood as an array of criteria, processes, moments that prevent the implementation of socioeconomic needs and interests or form a threat to them and the subjects of economic activity.

Аннотация. Опасность в общем, а не только социально-экономическая, считается такой вследствие того, что она формирует угрозу разрушения объекта, или наносит ему вред. Опасность социально-экономической защищенности имеет возможность быть определена в окончательном виде как некоторый вред, интегральный показатель которого охарактеризовывает уровень понижения социально-экономического потенциала за конкретное временя. Под опасностью понимается массив критериев, процессов, моментов, препятствующих реализации социально-экономических необходимостей и интересов или же формирующих угрозу для них и субъектов хоздеятельности.

Keywords: socio-economic security; the government; society; enterprise; employee; threat; security; interests; Economics, analysis, system.

Ключевые слова: социально-экономическая защищенность; государство; общество; предприятие; работник; угроза; защищенность; интересы; экономика, анализ, система.

One of the main components of the analysis of socio-economic security of the state is the monitoring of hazards, the dynamics of their accumulation and assessment of their impact. Their analysis was timed, in particular, resolution 42/165 of the UN General Assembly "International economic security" and the report of the UN Secretary-General "Concept of global economic security" (UN document a/42/314 of June 4, 1987) [1, p. 223].

In the scientific literature and official documents are offered various options for the composition of the socio-economic hazards $[2 ; 3 ; 4$, p. 70; 5, p. 57; 6, p. 893]. At the same time, there are trends towards its unlimited expansion, the inclusion of shortcomings characteristic of the transition state. In this situation, the problem itself is dissolved in the General properties of the 
financial and economic formation of the state, and on this basis it is not easy to form measures to ensure it.

More common in the scientific literature is the classification of hazards proposed by L. I. Abalkin [7, p. 12]. According to its systematization, the dangers are divided into: internal and external in relation to the subject. This aspect is supported by I. V. novices and A. Prokhozhev. The list of hazards differs in these researchers more or less degree of specification [8, p. 78; 9]. In our country, a special role in the systematization of the dangers of socio-economic security belongs to Myasnikovich [10].

The scale and stability of the action of the 1st group of factors lead to the conclusion that they, under specific criteria, have all chances to have negative results at the macroeconomic level and constitute a real danger to the socio-economic security of Belarus.

The action of the 2nd group of factors is caused by a consistent accumulation of long-term destructive effects in the process of reproduction of the main components of the economic system, namely:

* in the state and effectiveness of the application of innovative production and scientific and technical potential;

- in financial and economic relations of management.

There is an organic link between internal and external hazards. This" dichotomy "of socioeconomic security — the presence of dangers" from within "and" from outside" — is considered inevitable and insincere.

It is necessary to take a close look not only to the connection of internal and external hazards, but also to the messages and conditions in the economy itself, which form the environment for the emergence of adverse processes initiated from the outside. In these cases obliged to apply measures of economic and financial management, planning, forecasting, methods of social defense and control [11, p. 83].

Internal risk socio-economic security is the inability of businesses to self-preservation and self-development, weakness of an innovative factor in the ineffectiveness of control and regulation, inability to form any balance of interests and apply the skills of conflict resolution and incidents [12, p. 4].

Long-term preservation of internal hazards without effective financial and economic policy makes the national economy more vulnerable to external hazards.

Thus, the inability of Belarusian producers to meet domestic demand leads to a tightening of the economy's dependence on imports and foreign markets, primarily in terms of food, machinery and equipment, and foreign loans.

According to the view of some scientists the sharp decline in prices of export commodities or, on the contrary, the sharp increase in prices of imported products in terms of higher dependence on external markets is very unsafe for the state of the economy [13, p. 861].

The imposition of an embargo on trade with States or a group of States that are the main sales markets or suppliers of products is a threat. A significant level of dependence on the supply of certain types of products from one state or group of States is unacceptable, which allows these States to apply this dependence on other countries, which would allow creditors to impose financial and economic policies and the circumstances of the implementation of foreign economic relations.

Along with the export of classical products, it is necessary to make a more progressive export structure by the method of constructive diversification of exports, which can lead to the strengthening of foreign economic security of the state.

On other aspects of systematization of danger are divided into: 
Threats, intentionally generated by any other entity, and danger, spontaneously generated, are the unplanned results of some activities, the objective of the process of random changes;

- direct, i.e. causing negative modifications of the subject of protection, and indirect, leading to these changes only by means of intermediate cause-and-effect mechanisms, acting only under additional conditions;

- Current generating unnecessary changes through short intervals, and long-term (forwardlooking), the negative manifestations of which will come in quite a long time after the emergence of threats;

- Sporadic, generated by uncertain intervals of time, and systematic, occurring after specific intervals of time [14, p. 111].

These 4 aspects of hazard classification are closely related to the risk category. Socioeconomic hazards are considered to be the flip side of socio-economic gain and a simple condition of working in a competitive market environment. For a long time in the theory and practice of economic management, especially at the macro level, development was considered as a clearly deterministic process. Few had foreseen the unpredictability of the outcome of horseshoe, negative results or those of other disorders of the reproductive process, i.e. the inevitable socio-economic risk factors [15, p. 32].

The concept of risk in the strategy of socio-economic security includes two significant elements: risk assessment and risk management. Risk assessment is, as a rule, an expert probabilistic nature due to the uncertainty of the set of adverse results as the effects of objective factors, and taken decisions. It is possible to recognize that the Belarusian economy has a minimum amount of internal resistance, as a result of which literally all risk factors are able to form a situation of a critical nature. Risk management involves anticipating likely critical situations in order to prevent, mitigate and mitigate their results.

In connection with the above, the updated version of the concept of security is required to include a model of defense against risk. The proposed alignment is the task of the factor nature. He turned not PA external sources of destabilization, and the internal sources of adverse events. The method of response involves counter-action against any adverse events affecting the economy of the state, and as a consequence on society. Defense against risks involves the calculation and leading shares, the preparation of reserve resource potential.

There is a point of view, according to which only a few financial and economic dangers deserve to be associated with the task of socio-economic security. A huge share of the dangers associated with ordinary, everyday financial and economic activities and is its loss. What appears to be a danger in the short term has the potential to become a catalyst in the long term. The harm can be expressed in the loss of income or in the liquidation of certain sectors of the economy and does not go beyond the usual competition.

In the process of adopting conclusions, it is almost impossible to qualify in advance which external influences should be considered as signals for the revision of one's own, for example, technological orientation, and which - as undoubtedly not very favorable effects that require not adaptation, but counteraction. What's the point to talk about dangers and security, when the danger has already occurred, the security is already broken and "fatal" finale happened. Taking into account that the conclusions are based to a significant extent on the monitoring of the development of the phenomenon, from the standpoint of practical policy, it is advisable to include in a number of dangers of socio-economic security such negative external influences, which not only at this moment have all chances to lead to a critical strengthening of the negative trends in the financial and economic situation of society, but also serve as an obstacle to its financial and economic 
progress. Just this situation served as the ground for 2 more varieties of systematization of hazards: the degree of harm and in reality.

The assessment of the importance of socio-economic security implies the difference between the dangers of real, already accomplished changes, and probable ones - those that have all the chances to happen on some basis, as well as the introduction of the criteria of losses (damage)actual, expected, probable, compensated and uncompensated.

Depending on the nature of the resulting losses and the resources required to recover them, the negative effects of risk factors are likely to occur at the local level (within individual regions, population groups, enterprises), meso-level (within regions and segments of the economy), national and international levels. The choice of species provide more complete protection is achieved when compared in a specific case, countervailing measures and preventive measures in terms of "minimum harm" or "minimum total losses and costs" [16, p. 72].

Expert estimates of losses, the right to redress from those or other critical situations, are able to take time to collect society's resources to restore and finding the strength and durability of socioeconomic development, but also to prevent destabilization results [17]. To this end, we are introducing fundamentally new characteristics for our system of financial and economic analysis, information and calculations "compensation resources" and "compensation potential". There are specific differences between them.

Compensation resources, as a more specific concept, are close in value to the classical insurance, additional or "emergency" stock. They correspond to the concept of loss or harm (expected, actual), which in any particular case is limited to certain limits.

Compensation potential is a broader concept that characterizes the joint capacity of the economy of the state to respond to dangerous situations, to warn and to pass them, to restore the strength and stability of the processes of economic, social and environmental development in case of their violation in a particular sector of the economy, in a particular significant region.

The potential of direct compensation implies material reserves and reserves of production and non-production nature; special reserves, their territorial location; adequate auxiliary transport capacity for the delivery of material resources in the space of localization of critical situations; spare capacity, especially in the energy sectors of the economy, as well as technical methods for carrying out serious restoration work; maintenance of spare ways of providing social assistance and habituation of the population.

Potential compensation is characterized by these indicators as cash reserves (plus foreign exchange), insurance systems, the probability of foreign aid, the ability of charitable funds, the formation of compensation functions and mobility of health systems, the ability of mobile retraining of employees.

And, in the end, the risks have all chances to be classified according to the content of appropriate changes into internal economic, socio-political, foreign economic and foreign policy, organizational-legal, technological and environmental, as well as combined, combining at the same time a number of these significant qualities (Tables 1, 2, 3).

In the graph the source of exposure + means presence, - then the unavailability of this source. In the column the level of impact ++ means a significant level, + average, - a minor level of impact. It should be noted that this differentiation is a very difficult scientific task. In "pure form" the content of these or other factors can not be identified literally, because in real life financial and economic processes are inextricably intertwined with socio-political and moral-psychological. But it is possible and necessary to open the essence and the main direction of these processes, objectively taking into account their role and meaning. 
Table 1.

CLASSIFICATION OF INTERNAL ECONOMIC RISKS OF SOCIO-ECONOMIC SECURITY

\begin{tabular}{|c|c|c|c|c|}
\hline \multirow[t]{2}{*}{ Types and nature of hazards } & \multicolumn{2}{|c|}{ Sources of exposure } & \multicolumn{2}{|c|}{ Impact level } \\
\hline & External & $\begin{array}{l}\text { Internal } \\
\text { territorial }\end{array}$ & State & Region \\
\hline $\begin{array}{l}\text { 1. Decline in production rates and degradation of } \\
\text { knowledge-intensive industries }\end{array}$ & & & ++ & + \\
\hline 2. Reduced investment and innovation activity & + & + & ++ & + \\
\hline 3. Financial and economic destabilization & + & - & ++ & + \\
\hline $\begin{array}{l}\text { 4. Financial and economic difficulties of high-tech } \\
\text { production conversion }\end{array}$ & + & + & ++ & ++ \\
\hline $\begin{array}{l}\text { 5. Increasing difficulties in the provision of primary } \\
\text { resources }\end{array}$ & + & & + & + \\
\hline $\begin{array}{l}\text { 6. Stagnation and technological backwardness of } \\
\text { traditional industries }\end{array}$ & + & + & + & + \\
\hline $\begin{array}{l}\text { 7. St uncompetitive Belarusian technologies and } \\
\text { products }\end{array}$ & + & + & ++ & + \\
\hline 8. The destruction of industry technical relations & + & & ++ & + \\
\hline 9. Insufficient budget for R \& d & + & & ++ & \\
\hline 10. Deterioration of the material and technical base & + & + & + & + \\
\hline 11. Lack of demand for research results & + & + & + & \\
\hline
\end{tabular}

Source: elaboration of author

Table 2 .

\section{CLASSIFICATION OF EXTERNAL ECONOMIC DANGERS OF SOCIO-ECONOMIC SECURITY}

\begin{tabular}{lccccc}
\hline \multicolumn{1}{c}{ Types and nature of hazards } & Sources of exposure & \multicolumn{2}{c}{ Impact level } \\
\cline { 2 - 6 } & External & $\begin{array}{c}\text { Nutritaria } \\
\text { n alnye }\end{array}$ & State & Region \\
\hline 1. Formation of technological and financial dependence & ++ & + & ++ & + \\
on highly developed countries & & & & & \\
2. External technological dictate & + & & ++ & \\
3. Low competitiveness of Belarusian technologies & + & + & ++ & + \\
4. Outflow of highly qualified personnel abroad & + & + & + & \\
\hline
\end{tabular}

Source: elaboration of author

Table 3.

\section{CLASSIFICATION OF SOCIO-ECONOMIC SECURITY HAZARDS}

\begin{tabular}{|c|c|c|c|c|}
\hline \multirow[t]{2}{*}{ Types and nature of hazards } & \multicolumn{2}{|c|}{ Sources of exposure } & \multicolumn{2}{|c|}{ Exposure level } \\
\hline & External & $\begin{array}{c}\text { Nutritaria } \\
n \text { alnye }\end{array}$ & State & Region \\
\hline 1. Domestic economic & & & ++ & + \\
\hline 1.1.The decline in investment based on & + & + & ++ & + \\
\hline 1.2. Financial & + & & ++ & + \\
\hline 1.3. Financial and economic difficulties of conversion & + & + & ++ & ++ \\
\hline 1.4. The increasing difficulties in the supply of & + & & + & + \\
\hline 1.5. Stagnation and technological backwardness & + & + & + & \\
\hline 1.6. Non-competitiveness of the Belarusian industry & + & + & ++ & + \\
\hline 1.7. Destruction of industry links & + & & ++ & + \\
\hline 1.8. Lack of budget & + & & ++ & \\
\hline 1.9. Deterioration of logistics & + & + & + & + \\
\hline
\end{tabular}




\begin{tabular}{|c|c|c|c|c|}
\hline \multirow[t]{2}{*}{ Types and nature of hazards } & \multicolumn{2}{|c|}{ Sources of exposure } & \multicolumn{2}{|c|}{ Exposure level } \\
\hline & External & $\begin{array}{l}\text { Nutritaria } \\
\text { n alnye }\end{array}$ & State & Region \\
\hline 1.10. Lack of demand for products & + & + & + & \\
\hline 2. Socio-political & & + & & ++ \\
\hline 2.1. Growing needs & & + & & + \\
\hline 2.2. The increase in social spending & + & & ++ & ++ \\
\hline 2.3. The worsening of the demographic situation & + & + & + & + \\
\hline 2.4. Deterioration of society's morale & + & + & + & + \\
\hline 2.5. The fall of the authority of the government & + & & + & + \\
\hline 3. Foreign economic and foreign policy & ++ & + & ++ & + \\
\hline 3.1. External factor & + & & ++ & \\
\hline 3.2. Low competitiveness & + & + & ++ & + \\
\hline 3.3. Outflow of highly qualified personnel & + & + & + & \\
\hline 4. Organizational-legal & + & + & ++ & + \\
\hline 4.1. Weakening of mechanisms & + & & ++ & + \\
\hline 4.2. The emergence of irreversible prerequisites & & + & & + \\
\hline 4.3. Effective use of funds & + & & ++ & + \\
\hline 4.4. Delay or erroneous actions & + & & ++ & + \\
\hline 4.5. Incorrect placement of frames & + & & ++ & + \\
\hline 4.6. Imperfect legislation & + & & + & \\
\hline 5. Technological and technosphere & + & & ++ & + \\
\hline $\begin{array}{l}\text { 5.1. Location of high-risk industries in densely } \\
\text { populated regions }\end{array}$ & & & + & + \\
\hline 5.2. Sharp decline in fixed capital investment & + & + & + & + \\
\hline $\begin{array}{l}\text { 5.3. A sharp increase in the cost of protection of the } \\
\text { facility due to the high risk of intentional or } \\
\text { unintentional accidents }\end{array}$ & + & + & + & + \\
\hline 5.4. Insufficient development of the resource base & & + & + & + \\
\hline 6. Environmental & & & + & + \\
\hline 6.1. Use of resource-intensive technologies & & & + & + \\
\hline 6.2. Industry impact factors & + & + & + & + \\
\hline 7. Informational & + & + & + & + \\
\hline 7.1. Underestimation of information threats & + & + & + & + \\
\hline 7.2. Insufficient legal protection & ++ & & ++ & \\
\hline
\end{tabular}

Source: elaboration of author

So it can be concluded that the need for the formulation of the problem of socio-economic security is formed by the presence of external (exogenous) and internal (endogenous) threats to the economic structure (Table 4) and society.

External destructive factors may include, for example, globalization, financial, economic and political instability, imperfection of legislation, the impact of rivals, dynamic mobility of the securities market, unavailability of reliable data for investors on the state of the market and issuers of securities, etc. To the array of internal factors that generate risks, fraught with risks of "bad situations", may include limited ability to insure risks, inaccessibility of accurate technologies of interaction of market participants, still taking place institutional incompleteness of the market economy, a complicated system of relationships in the real and financial sectors, any of which has the opportunity to act as a focus of crisis manifestations, etc.

Table 4. 


\section{DIRECT AND INDIRECT THREATS TO THE SECURITY} OF THE REAL SECTOR OF THE ECONOMY

\begin{tabular}{|c|c|}
\hline threat & threats \\
\hline $\begin{array}{l}\text { 1. Decline (stagnation) of production } \\
\text { 2. Structural deformity of the country's industry } \\
\text { 3. High age level of fixed assets } \\
\text { 4. Low technical and technological level of } \\
\text { production } \\
\text { 5. Low innovation activity in most industries } \\
\text { 6. Crisis the deterioration of the innovation potential } \\
\text { 7. Increase of material and energy consumption of } \\
\text { products } \\
\text { 8. Rising unemployment } \\
\text { 9. Reduction of professional qualification level of } \\
\text { personnel } \\
\text { 10. Criminalization of corporate relations } \\
\text { 11. Weak use of natural resource potential } \\
\text { 12. Corruption in the regulation of property relations }\end{array}$ & $\begin{array}{l}\text { 1. Low competitiveness of products } \\
\text { 2. The predominance of raw material } \\
\text { orientation of exports } \\
\text { 3. Dependence on imports of machinery and } \\
\text { technology } \\
4 \text {. Discriminatory measures against domestic } \\
\text { goods in world markets } \\
5 \text {. Inefficiency of the stock market in terms of } \\
\text { attracting investments } \\
6 \text {. The crime fighting for the redistribution of } \\
\text { property } \\
7 \text { Inefficient currency, tax and customs policy } \\
\text { of the state } \\
8 \text {. Weak credit and banking support for the real } \\
\text { sector } \\
\text { 9. Capital flight from the country } \\
10 \text {. Availability of inter-industry price disparities } \\
\text { 11. No real protectionist policy of the state }\end{array}$ \\
\hline
\end{tabular}

Source: elaboration of author

In today's environment, a special role is played by external hazards. Among the main reasons for their appearance, in our opinion, it should be noted the following:

- Development of the process of transnationalization of financial and economic relations, integration of public financial markets, and internationalization of the global economy (called globalization);

- The relative weakening of the regulation of global financial markets with an increase in their size and turnover of operations, the rise of competition between them;

- Expansion of the global financial and economic system by entering the international economy of developing countries (increasing international instability);

- constant growth of a large mass of capital (including their flows between countries), significant mobility of which (due to the increase in the speed of transfer from the 1st market to the 2nd) forms a difficult situation, a high level of concentration of monetary resources at the macroeconomic level (budget systems of countries and global organizations) and the level of interstate financial integration;

- Growing autonomy of financial conglomerates or financial and economic entities of the state (TNCs, tnbs, etc.) with significant financial and economic power, increasing their impact on the economic structures of individual countries;

- the growth of the intensity of financial transactions, the high level of mobility and communication of financial and economic markets (for example, the decline, first formed in a certain one market, has the ability to quickly spread to others, which can have non-controllable results for the entire global economic system) on the basis of advanced information technologies;

- The interpenetration of domestic and foreign policy of countries (including the Republic of Belarus), which are increasingly dependent on global Finance;

- increased competition and friction between Belarus and other countries in the financial, economic and other spheres (loss of certain markets, discrimination of Belarusian producers in global markets, etc.);

- the harm caused to the Belarusian export using baseless discriminatory measures; 
- Excessive dependence of the economies of States (in particular the public sector) on foreign speculative capital, making their financial systems very vulnerable.

The conceptual division of the dangers of socio-economic security into internal and external is justified (used) in most works and publications on socio-economic security. At the same time, taking into account the complexity of the manifestations and forms of influence of various dangers on the formation of the economy, we consider it important to deepen the introduction of the systematization of the hazard scheme, dividing the danger (at the analytical level) into direct and indirect hazards.

The need for such an approach to the analysis of risks is connected, as we see it, not only with the definition of unfavorable areas of development, but also the introduction of more complex equipment to identify the entire array of concomitant crisis deviations associated with certain forms of the impact of hazards on the development of individual components of the state economy. Previously, a classification scheme of hazards with their division into direct and indirect was proposed.

So, it is necessary to note among the main dangers of socio-economic security of Belarus:

- the preservation of the structural degradation of the economy;

* Low degree of innovation and scientific and technological capacity;

* increased dependence on imports;

* deepening the property stratification of society;

* Significant amounts of debt;

* Excessive openness of the economy;

- Insufficient pace of development of innovation sector;

* High and rising inflation.

According to the view of the author now needs to direct more attention to depoakote that bears the global recession. Since the current methods of ensuring the socio-economic security of the Republic of Belarus are implemented on the hypothesis of a constant and long-term rise, they are not designed for the possibility of financial and economic regression, in which there will be a decrease in demand for products exported from the state.

The efficiency of the production facilities formed by the state and associated large business is obviously calculated on the current demand indicator, which subsequently has the opportunity to turn into large economic losses, primarily for the country.

The possibility of these losses is due to the fact that the state is considered to be a large investor in the relevant projects (primarily in the provision of their infrastructure) and is closely connected with business, which in the case of a recession, will most likely take over the compensation of their losses. This poses a serious threat to social and economic security.

It is also necessary to mark the toughening of such dangers of social and economic security of the Republic of Belarus as: materials;

- Growing dependence of the economy on changes in global prices for energy and other raw

- increasing private debt;

- The probability of a lack of balance of payments and the strengthening of the state's dependence on the inflow of foreign investment.

\section{References:}

1. Puzikov, V. V. (2013). Osnovy teorii obespecheniya natsional'noi. Minsk. 512.

2. Shvaiba, D. (2019). Dynamic regression models of forecasting indicators of social and economic security. Bulletin of Science and Practice, 5(1), 249-257. 
3. Shvaiba, D. (2018). The content of the forecast of socio-economic security of the industrial sector of the Republic of Belarus. Bulletin of Science and Practice, 4(8), 177-182.

4. Pospelova, E. B. (2015). Ekonomicheskoe neravenstvo i sotsial'naya spravedlivost' na sovremennom etape v razvitykh stranakh. Innovatsii i investitsii, (9). 70-71.

5. Ross, G. V., \& Likhtenshtein, V. E. (2016). Zakony ekonomicheskogo khaosa. Informatizatsiya i svyaz', (1). 56-61.

6. Taroyan, M. M. (2016). Ekonomicheskaya bezopasnost' Rossii v sisteme sotsial'noekonomicheskikh prioritetov strany. Ekonomika i predprinimatel'stvo, (12/2). 891-895.

7. Abalkin L. I. (1994). Ekonomicheskaya bezopasnost' Rossii: ugrozy i ikh otrazhennee. Voprosy ekonomiki, (12). 4-16.

8. Prokhozhev, A. A. (2006). Zhiznenno vazhnye interesy lichnosti, obshchestva, gosudarstva. In Teoriya razvitiya i bezopasnosti cheloveka i obshchestva, 77-83.

9. Novichkov, I. V. (2000). Regionalizatsiya ekonomicheskom bezopasnosti v usloviyakh sotsial'noi modernizatsii. Saratov: Izd-vo Sarat. un-ta. 18.

10. Myasnikovich, M. V., Polonik, S. S., \& Puzikov, V. V. (2006). Upravlenie sistemoi obespecheniya ekonomicheskoi bezopasnosti. Minsk, Pravo i ekonomika. 378.

11. Kochurova, L. I. (2004). Real'nyi sektor razviya rynka: teoreticheskie osnovy, model', ekonomicheskie otnosheniya. Moscow. Ekonomika. 212.

12. Avramenko, A. I. (2015). Nekotorye vyzovy i ugrozy sotsial'no-ekonomicheskogo razvitiya Belarusi. In Ekonomiko-pravovye voprosy obespecheniya ekonomicheskoi bezopasnosti Respubliki Belarus': tez. dokl. resp. nauch.-prakt. konf., Minsk, 11 dek. 2015. Minsk, 3-6.

13. Sengachov, V. K. (2005). Ekonomicheskaya bezopasnost' Rossii. Moscow. Delo. 895.

14. Perevalov, D. V., \& Misnik, V. L. (2015). Opredelenie, modelirovanie i otsenka otdel'nykh tekhnogennykh i sotsial'nykh ugroz bezopasnosti kriticheski vazhnykh ob"ektov. Pravo.by, 2 (34). 110-115.

15. Oleinikov, E. A. (1999). Ekonomicheskaya bezopasnost': teoriya i praktika. Moscow. Klassika plyus. 409.

16. Senchagov, V. K. (2001). Ekonomicheskaya bezopasnost' kak osnova obespecheniya natsional'noi bezopasnosti Rossii. Vopr. Ekonomiki, (8). 64-79.

17. Lipatova, L. N., \& Modin, E. V. (2015). Sotsial'no-demograficheskie faktory ekonomicheskoi bezopasnosti. In Mezhdunarodnoe sotrudnichestvo: sotsial'no-ekonomicheskie $i$ pravovye aspekty: XV Makar. nauch. chteniya, Saransk, 28 marta 2015 g. Saransk, 363-371.

\section{Список литературы:}

1. Пузиков В. В. Основы теории обеспечения национальной. Минск. 2013. 512 с.

2. Shvaiba D. Dynamic regression models of forecasting indicators of social and economic security // Бюллетень науки и практики. 2019. Т. 5. №1. С. 249-257.

3. Shvaiba D. The content of the forecast of socio-economic security of the industrial sector of the Republic of Belarus // Бюллетень науки и практики. 2018. Т. 4. №8. С. 177-182.

4. Поспелова Е. Б. Экономическое неравенство и социальная справедливость на современном этапе в развитых странах // Инновации и инвестиции. 2015. № 9. С. 70-71.

5. Росс Г. В., Лихтенштейн В. Е. Законы экономического хаоса // Информатизация и связь. 2016. № 1. С. 56-61.

6. Тароян М. М. Экономическая безопасность России в системе социальноэкономических приоритетов страны // Экономика и предпринимательство. 2016. № 12/2. С. 891-895. 
7. Абалкин Л. И. Экономическая безопасность России: угрозы и их отраженнее // Вопросы экономики. 1994. № 12. С. 4-16.

8. Прохожев А. А. Жизненно важные интересы личности, общества, государства // Теория развития и безопасности человека и общества. М., 2006. С. 77-83.

9. Новичков И. В. Регионализация экономическом безопасности в условиях социальной модернизации. Саратов: Изд-во Сарат. ун-та. 2000. 18 с.

10. Мясникович М. В., Полоник С. С., Пузиков В. В. Управление системой обеспечения экономической безопасности. Минск: Право и экономика. 2006. 378 с.

11. Кочурова Л. И. Реальный сектор развия рынка: теоретические основы, модель, экономические отношения. М.: Экономика. 2004. 212 с.

12. Авраменко А. И. Некоторые вызовы и угрозы социально-экономического развития Беларуси // Экономико-правовые вопросы обеспечения экономической безопасности Республики Беларусь: тез. докл. респ. науч.-практ. конф., Минск, 11 дек. 2015 г. Минск. 2015. C. 3-6.

13. Сенгачов В. К. Экономическая безопасность России. М.: Дело. 2005. 895 с.

14. Перевалов Д. В., Мисник В. Л. Определение, моделирование и оценка отдельных техногенных и социальных угроз безопасности критически важных объектов // Право.by. 2015. № 2 (34). С. 110-115.

15. Олейников Е. А. Экономическая безопасность: теория и практика. М.: Классика плюс. 1999. 409 с.

16. Сенчагов В. К. Экономическая безопасность как основа обеспечения национальной безопасности России // Вопр. экономики. 2001. № 8. С. 64-79.

17. Липатова Л. Н., Модин Е. В. Социально-демографические факторы экономической безопасности // Международное сотрудничество: социально-экономические и правовые аспекты: XV Макар. науч. чтения, Саранск, 28 марта 2015 г. Саранск. 2015. C. 363-371.

Работа поступила

в редакичию 16.05.2019 2.
Принята к публикаичии 19.05.2019 2.

Ссылка для циитирования:

Shvaiba D. Classification of Threats to the Socio-Economic Security of the Country // Бюллетень науки и практики. 2019. Т. 5. №6. С. 326-335. https://doi.org/10.33619/2414$2948 / 43 / 43$

Cite as (APA):

Shvaiba, D. (2019). Classification of Threats to the Socio-Economic Security of the Country. Bulletin of Science and Practice, 5(6), 326-335. https://doi.org/10.33619/2414-2948/43/43 